\section{B A Institute of \\ yk Business Administration \\ 六下 \\ Karachi \\ Leadership and Ideas for Tomorrow}

Business Review

Volume 3 Issue 1 January-June 2008

$1-1-2008$

\title{
The role of governance and its influence on quality enhancing mechanism in higher education
}

\author{
Syed Naeem Ahmed \\ Institute of Education and Social Sciences Hamdard University, Karachi, Pakistan
}

Follow this and additional works at: https://ir.iba.edu.pk/businessreview

Part of the Higher Education Commons

(c) (i)

This work is licensed under a Creative Commons Attribution 4.0 International License.

\section{Recommended Citation}

Ahmed, S. N. (2008). The role of governance and its influence on quality enhancing mechanism in higher education. Business Review, 3(1), 145-152. Retrieved from https://doi.org/10.54784/1990-6587.1138

This article is brought to you by iRepository for open access under the Creative Commons Attribution 4.0 License and is available at https://ir.iba.edu.pk/businessreview/vol3/iss1/12. For more information, please contact irepository@iba.edu.pk. 


\title{
DISCUSSION
}

\section{The role of Governance and its influence on quality enhancing mechanism in Higher Education}

\author{
Syed Naeem Ahmed \\ Institute of Education and Social Sciences \\ Hamdard University, Karachi, Pakistan
}

\section{INTRODUCTION:}

$\mathrm{U}$

Tniversities live in complex contexts, compete in many different marketplaces, and perform a bewildering array of highly sophisticated services for many diverse constituencies. Although universities focus their efforts primarily on the key dimensions of teaching and research, they engage in a wide range of additional activities derived from the expertise and resources accumulated in support of teaching and research. With the expansion of the assessment of quality at higher education, budgetary allocation, and particularly private sector involvement at higher education for the last five years, institutions became much more complex and the role of Governance and its influence on quality enhancing mechanism became an evermore-popular topic. The purpose of this paper is to highlight different issues among university leaders, teaching community and research students on the role of governance and its influence on quality enhancing mechanism in higher education.

\section{WHAT IS GOVERNANCE AND WHAT IS IT ALL ABOUT?}

Taylor (1996) defined governance as

"A collective effort, through smooth and suitable process, to take actions that advance a shared purpose consistent with the institution's mission.”

Schuller (2003) defined university governance as

"A social process entailing responsibility for the effective and economical planning and regulation of the operation of the university. In the fulfillment of a given purpose or task, such responsibility may involve judgment and decision making in determining plans, using data to control performance and progress against plans; and guidance, integration, motivation and supervision of the personnel composing the university, carrying out its operation" 


\section{WHAT IS QUALITY?}

Quality and related issues discussed at Ministerial Round Table on Quality Education, UNESCO, 2003 maintain:

"The Quality has become a dynamic concept that has constantly to adapt to a world whose societies are undergoing profound social and economic transformation. Encouragement for future-oriented thinking and anticipation is gaining importance. Old notions of quality are no longer enough....despite the different contexts there are many common elements in the pursuit of a quality education, which should equip all people, women and men, to be fully participating members of their own communities and also citizens of the world”.

As quality is a dynamic process and governance is very much involved in the process of institutional operation and management, this paper raises some issues related with the role of governance and quality linkages for Pakistani Universities.

\section{EFFECTIVENESS}

Is a democratic or participative approach more effective than the managerial style? Does decentralization and devolution of power to departments assist or hinder effective management? Do we need more training for leadership and for governance?

It is important to think seriously about management and governance questions because effective management and good governance assist academic performance and strengthen universities' ability to withstand the vagaries of erratic funding policies and environmental turbulence. The board of governors and the general Faculties Council, at the level of institutional governance, rely on effective structures, powerful instruments and time-honored techniques to ensure that the University honors its mission, mandate, values and vision while complying with legislative requirements Perhaps, above all, the process gives universities confidence in facing the future. HEC (Higher Education Commission) medium term development framework 2005-10 clearly states that

'Improvement in university governance and management is required to improve the quality of education and research'.

But, how? We have to be very clear in our strategy i.e. to bring change in the institutions. Change in governance structure; Change in planning system; Change in management style; Change in operation and implementation; and change in the evaluation system etc. Shamsh Kassim-Lakha (1998) quoted Tanner in an international seminar at Karachi, the basic statement to bring change: 
"A reasonable university adapts itself to the world around it. An unreasonable one expects the world to change according to its ideas. Therefore, all progress depends on the unreasonable university."

Change does not mean to make brand new policy initiative or bold restructuring. Improving University effectiveness has more to do with examining each related activity on a holistic basis. Universities are interlocking organizations in which all the parts are interdependent. To improve university management, we need to train and educate a wider proportion of our staff in what the management issues are and how to approach them to bring the desired change? It is not necessary to delay this until they become deans or pro vice chancellors or until they have been consigned to a specialist administrative area for a number of years. If we are to take institutional management seriously, we must prepare a subset of the younger generation of academics and administrators so that when they reach senior positions they understand the issues and approach them professionally.

Shamsh Kassim Lakha has also pointed out in his paper that quality of governance in public sector universities has suffered most due to the lack of political will; political appointments to governing bodies; induction of trustees and governors of inadequate quality; polarization of syndicates and senate; and appointment of university leadership solely at the discretion of the chancellor who most often is himself a political appointee or a political figure.

Dr. Tariq Rehman rightly stated

"The highest rank in the military goes to military officers, the highest rank in the bureaucracy goes to bureaucrats, and the highest rank in the judiciary goes to a judge. However in university the higher rank may go to someone who started his career as a lieutenant or an assistant commissioner".

Francis (1998) suggested that good universities make for good governance by screening the best for the top. But they do more too. A university that honestly pursues objective standards of admission, performance and accomplishment, without regard to a person's affiliation or other qualities, is a school with a moral vision that is badly needed in societies whose governments are endemically corrupted by special loyalties to kin and kind.

Regarding private universities it seems that their autonomy for governance, recruitment, enrollment and curriculum have an opportunity to address the change issues, which the public sector finds most troublesome because private universities are not constrained by lack of ability or undue influence. 
We therefore do not need new governance fads or tool kits but more investment in thinking about the effectiveness of university governance.

\section{SETTING OBJECTIVES:}

The second issue relates to the value of setting objectives. There seems to be general agreement that the preparation of institutional plans and missions statements, and university assists management and gives governing bodies a more strategic role. Governance may be treated as the force which lays down the object for which an organization and its management are to strive for and the broad policies under which they are to operate governance may also be treated as the force which leads and directs to the realization of desired goals and objectives.

After a careful study of powers of the private and public universities it is found that the university acts are almost more or less same and in some cases (especially in the cases of public universities case), they are merely replicated. It is found that not a single article in universities' act is related to the assurance of quality in universities. Even the model university act of Government of Pakistan (2002) has nothing to say directly about quality assurance and any kind of standardization. The draft rules and regulations used by public sector universities (which are supposed to be tried and tested) are not conversant with the issue of quality assurance, and the governance and quality linkages. It is therefore highly satisfying that the university act possess the objectives that will not only elevate the level of higher education but will also ensure the quality of higher education through the establishment of Quality Enhancement Cell (QEC) in all universities.

Universities can function as quality engines for a nation. They accumulate resources of all kinds to support the highest possible levels of faculty and student quality. Faculty and students, pursuing their individual goals within the context of the university's academic program and guilds, develop their skills and use them to create additional value either in the form of enhanced capabilities as graduates at all levels, or of contributions to new knowledge through research. In achieving these aims, the quality engine of the Pakistani Universities should operate multiple separate domains. One domain derives the teaching enterprise at the undergraduate level; another connects graduate and professional studies to the work of the faculty. A third sustains the research of the faculty and their much needed collaboration, while a fourth translates those research accomplishments into patents, licenses, and other assets of value to the nation and the world.

The Revision of Charters and statutes to alter the composition of the governing bodies may therefore be envisioned as one of the priorities to ensure quality at higher levels of education. 


\section{COMPETITIVENESS AND COLLABORATION}

A related major issue pertains to the balance between competitiveness and collaboration, both within and between the institutions. The competition and collaboration within an institute to ensure quality rests on two assumptions:

First, students, teachers and administrators in the universities are, and should be, homogeneous communities and that they coalesce and should coalesce into a wellintegrated university community; Too often academics and administrators in established disciplines pluck out of the already made managerial solutions from elsewhere they may have heard on discussed at a conference and present them as newly minted answers to their own problems.

Secondly, universities seem to outside world to be overly democratic but are often extremely hierarchical, excluding the most knowledgeable people on particular management issues from participation in decision making on the issues in which they are the most expert. Universities are often deeply resistant to flat structures where communication lines are short and decisions can be taken quickly, preferring extended decision making structures where process trumps over timeliness. Too often relation between academic and professional managers are confused by considerations of status when it is abundantly clear that partnership, collaboration, a sense of equality and open discussion encourages creative thinking and innovative ideas.

Programme quality assurance rightly belongs to knowledgeable peers who are the best judges and most effective guardians of quality standards. This means inviting objective and respective colleagues to review and report to the governing board. Strength and weaknesses of the faculty and board must be identified through review committees. Trustees have then little difficulty convincing either themselves or the faculty of what needed to be done to redress the weaknesses.

Many of the issues concerning the competitiveness and collaboration between the governance of different institutions revolve around the relationship between the Federal and provincial government, the national funding bodies and higher education institution. The implementation and safeguarding of the quality of the university's educational programs should not rely solely on government and its agencies. Autonomy is a condition precedent if the universities are to discharge their duties and obligations effectively and efficiently as regards imparting and advancement of knowledge and also making their unique contribution to the life and development of the nation.

Shamsh Kassam-Lakha has pointed out that a young university aiming to learn from an older, established institution and perhaps hoping in the process to gain 'reflected 
glory’ and improving its image through such a linkage will be disappointed, unless it too can offer something in return to the mature university. This could be done by reimbursement of the cost of such linkages - the most common method; through collaborative working arrangements that envisage exchange of faculty, joint research project and exchange programs for students. Such linkages would require much nurturing and almost every linkage will require some financial support (but, the less money that changes hands, the better). However, the most successful linkages are the faculty members among various instiutions.

\section{CONCLUSION}

It is very important to ensure the role of governance of universities to be effective, so that the institutions control the selection of students, selection and retention of faculty and the curriculum that is offered and the awarding of degrees. What has been achieved so far with respect to quality and governance is only a beginning. We have to be optimistic enough to hope that this issue will be taken seriously to bring quality at higher education.

\section{REFERENCES}

Coaldrak P. et.al (2003). Issues in Australian University Governance. Retrieved on 01 December, 2006. www.aph.gov.au/LIBRARY/Pubs/RP/1999-2000/2000rp02.htm

Edward M. (2004). University Governance-A mapping and some issues. Retrieved on 29 November 2006. www.atem.org.au/pdf/Governance.pdf

Higher Education Commission Pakistan, Medium term development Framework 2005-10, pp. 47-50

Kaul J.N. (1990). Governance of Universities-Autonomy of the Universities Community. New Delhi:Abhinav publication.

Lakha S. (1998). Higher Education: A Pathway to Development. Karachi: Oxford University Press, .

Lombardi J.V. et.al (2002). University Organization, Governance and competitiveness. Retrieved on 26 November 2006.

www.thecenter.ufl.edu/UniversityOrganization.pdf

Ordinance No. CXX of 2002 — an ordinance to constitute and restructure Universities set up by the Federal Government, Pakistan. 
https://ir.iba.edu.pk/businessreview/vol3/iss1/12

DOI: https://doi.org/10.54784/1990-6587.1138

Business Review - Volume 3 Number 1

January - June 2008

Renson S. et. al (1986). The Changing Government of Education. London: Allen and Unwin.

Smith R.H.T. (2002). Higher Education at Cross Roads-Governance, Management and workplace relation. Retrieved on 30 November 2006. www.dest.gov.au/.../key_priorities/documents/HEd_Workplace_Productivity_Progr amme_DP0705_rtf.htm

The Centre for Higher Education Transformation, Islamabad, Pakistan. State of Higher Education in Pakistan 2005: Quality. pp.46-49

Tom S. (1992). The future of Higher Education. USA: Open University Press.

Moral truth can be conceived in thought. One can have feelings about it. One can will to live it. But moral truth may have been penetrated and possessed in all these ways, and escape us still. Deeper even than consciousness there is our being itself - our very substance, our nature. Only those truths which have entered into this last region, which have become ourselves, become spontaneous and involuntary as well as voluntary, unconscious as well as conscious, are really our life - that is to say, something more than property. So long as we are able to distinguish any space whatever between Truth and us we remain outside it. The thought, the feeling, the desire or the consciousness of life may not be quite life. To become divine is then the aim of life. Then only can truth be said to be ours beyond the possibility of loss. It is no longer outside us, nor in a sense even in us, but we are it, and it is we.

AMIEL 
https://ir.iba.edu.pk/businessreview/vol3/iss1/12

DOI: https://doi.org/10.54784/1990-6587.1138

Business Review - Volume 3 Number 1

January - June 2008

“Change - real change - comes from the inside out. It doesn't come from hacking at the leaves of attitude and behavior with quick fix personality ethic techniques. It comes from striking at the root - the fabric of our thought, the fundamental, essential paradigms, which give definition to our character and create the lens through which we see the world. In the words of Amiel,

Moral truth can be conceived in thought. One can have feelings about it. One can will to live it. But moral truth may have been penetrated and possessed in all these ways, and escape us still. Deeper even than consciousness there is our being itself - our very substance, our nature. Only those truths which have entered into this last region, which have become ourselves, become spontaneous and involuntary as voluntary, unconscious as well as conscious, are really our life - that is to say, something more than property. So long as we are able to distinguish any space whatever between Truth and us we remain outside it. The thought, the feeling, the desire or the consciousness of life may not be quite life. To become divine is then the aim of life. Then only can truth be said to be ours beyond the possibility of loss. It is no longer outside us, nor in a sense even in us, but we are it, and it is we."

Stephen R. Covey

152 